Отримано: 15 квітня 2019 року

Прорецензовано: 22 травня 2019 року

Прийнято до друку: 23 травня 2019 року

e-mail: Yaroslava krapchatova@ukr.net

s.v.p@3g.ua

DOI: $10.25264 / 2519-2558-2019-6(74)-175-178$
Yaroslava Krapchatova, Svitlana Petrenko. English listening competence as the object of self-assessment. Наукові записки Національного університету «Острозька академія»: серія «Філологія». Острог: Вид-во НаУОА, 2019. Вип. 6(74), червень. С. 175-178.

\author{
Yaroslava Krapchatova, \\ Candidate of sciences in pedagogics, docent, National Academy of Security Service of Ukraine \\ Svitlana Petrenko, \\ National Academy of Security Service of Ukraine
}

\title{
ENGLISH LISTENING COMPETENCE AS THE OBJECT OF SELF-ASSESSMENT
}

The article analyzes the concept of English listening competence which is considered as a set of attainment of phonetics, vocabulary, grammar; receptive (phonetic, lexical and grammatical) awareness; listening skills and the abilities of the individual to perceive, understand and respond in English based on a complex of dynamic interaction of relevant attainment, skills, and abilities. The components of English listening competence are thoroughly analyzed and described. The difference between the Independent Users B 2.1 and B 2.2. is researched. The main results include the following matters: the B 2.1 User can understand the main ideas of linguistically complex speech on special and abstract topics presented in a common dialect, including discussions on technical issues in the area of his / her field of knowledge. The B 2.1 User is able to follow a long and complex argument if the topic is rather familiar, and the way of speech is explicitly marked; while the B. 2.2 User is able to understand the spoken language, "live" or broadcast on TV or radio on familiar and unfamiliar topics that are commonly used in personal, social, academic or professional sphere. Only excessive background noise, specific discourse structure and / or using of idioms can affect the ability to understand speech messages.

Key words: English listening competence (ELC), phonetic, lexical and grammatical awareness, receptive phonetic, lexical, grammatical skills, auditory skills, ability, Independent User.

\section{Крапчатова Ярослава Анатоліївна,}

кандидат педагогічних наук, доцент, Національна академія Служби безпеки Украӥни

Петренко Світлана Володимирівна,

Національна академія Служби безпеки України

\section{АНЛОМОВНА КОМПЕТЕНТНІСТЬ В АУДІЮВАННІ ЯК ОБ’СКТ САМОКОНТРОЛЮ}

У статті аналізується поняття англомовної компетентності в аудіюванні (АКА), яка розглядається як сукупність (фонетичних, лексичних, граматичних) знань, рецептивних (фонетичних, лексичних і граматичних) навичок, аудитивних вмінь та здібностей, шо полягають в здатність особистості коректно сприймати, розуміти та реагувати комунікативно на мовлення носіїв або не носіїв англійської мови (мовлення яких наближається до норми), яка базується на складній і динамічній взаємодії відповідних знань, навичок, вмінь та комунікативних здібностей. Досліджуються і детально описуються окремі складові АКА: знання, навички, вміння та здатність. До розгляду пропонується зміст мовленнєвої компетентності в аудіюванні на рівні володіння В2 (незалежного користувача). Описується різничя між підрівнями В 2.1 та В 2.2.

Ключові слова: англомовна компетентність в аудіюванні, фонетичні, лексичні, граматичні знання, рецептивні лексичні, граматичні, фонетичні навички, аудитивні вміння, здатність, незалежний користувач.

According to World Language Standards for learning languages and assessment [2, p. 24] the level of English language competence in listening (ELC) Upper Intermediate B2 level (Independent user) should reflect the detailed learning structure and assessment of the ELC level in curriculum.

In teaching methodology of foreign language (FL) studies we should identify assessment criteria of lexical competence (L. V. Bankevich, O. F. Ivanova, S.Yu. Nikolaieva, N. S. Saienko); grammatical competence (V. V. Holubets, V. V. Osidak, T. V. Putintseva); lexical-grammatical competence (N. I. Krasyuk); phonetic competence (Yu. V. Golovach); cultural competence (S. I. Shuklyn); philological competence (K. O. Porechenkova); listening skills (O. V. Kmit); speaking competence (M. V. Mitina, O. O. Molokovich, O. S. Parnyugin, O. V. Tikhomirova, O. O. Ukrainska); reading competence (T. G. Korol, I. A. Tsaturova, G. B. Yudis); writing competence (D. Yu. Teleshev, T. R. Shapovalova).

The purpose of this article is to give a scientific credence of the term (ELC) in modern lingual-didactic discourse and analyze its components at the Upper Intermediate (Independent User) B2.1 and B2.2 levels.

Following I.H. Kolosovsky`s theory, listening is observed as an unexpressed, active inner process that is carried out with the help of reception, information processing and, finally, understanding or misunderstanding of the semantic content [3, p. 5].

According to S. Nikolaeva the concept "competence" is highlighted as a set of awareness and skills to respond successfully individual and social needs, act and perform set tasks. Each competence includes knowledge, awareness, skills and abilities such as validity, emotions, and behavior, that can be involved into life activities [5, c. 11-12].

A. M. Shchukin has analyzed competence (from Latin competence) as a set of knowledge, skills and awareness that are formed during the study of a discipline, as well as the ability to perform one or another activity on the basis of the acquired knowledge, skills and awareness [6 p.118].

Based on these connotations, we should consider ELC as a collection of (phonetic, lexical, grammatical) awareness, receptive (phonetic, lexical and grammatical) skills and auditory skills. Therefore, ELC is the ability of an individual to perceive clearly and thoroughly, understand and respond communicatively to native or foreign English speakers, based on the complex and dynamic interaction of relevant knowledge, abilities, awareness and communication skills [4, c. 32]. 
We should consider the ELC components more thoroughly. The competence mentioned above includes phonetic, lexical and grammatical knowledge and awareness. According to A. M. Shchukin, knowledge is a collection of data about system language and a set of rules of the system use in theoretical and practical activities [6, p. 84]. Therefore, in the teaching methodology of FL the terms theoretical knowledge related to the theory and practical awareness associated with practice are distinguished. Knowledge acts as the regulating and controlling mechanism of speech and is a starting point in the formation of receptive awareness and auditory skills. Consequently, students on the listening stage of the learning process should have knowledge corresponding to B2 level (Independent User).

Phonetic awareness as an ELC component deals with:

- phonemes and their articulation and acoustic characteristics, for example: long and short vowels, voiced and voiceless consonants, sequence of sounds, etc.;

- assimilation in phonetics, for example: reduction of unstressed vowels, assimilation, elision, allophonic variations at the edge of words, linking, etc.;

- phonetic structure of words, for example: root-morphemes, stress;

- intonation and its main components, for example: melody, rhythm, pause, utterance stress, tempo, timbre;

- types of tones, for example: descending, etc.;

- types of emphasis in the sentence, for example: logical emphasis (declarative knowledge).

- kind of intonation for enumeration, commands, instructions, requests, etc.;

- emphasis of the key pieces of information in a sentence, etc. (procedural knowledge) [4, p. 33-34].

Grammatical awareness deals with topically selected, structured grammar that students should acquire during a certain stage. Thus, at B2 level students should know:

- grammar terms, for example: definite/ indefinite article, auxiliary verbs, transitive and intransitive verbs, word order in a sentence, etc.;

- grammar morphology, for example: morphemes, word-formation (affixes, prefixes, suffixes);

- sentence forming elements, for example: numbers, use of gender, cases; Active / Passive Voice; Tenses;

- word categories, for example: nouns, verbs, adjectives, adverbs;

- word structure, for example: complex and compound words, phrases (simple, phrasal verbs, idioms), sentences (main, subordinate, clause);

- morphological transformation, for example: nominalization, affixation, transformation;

- agreement of tenses (declarative knowledge);

- instructions, advice, order, request, asking questions, etc.;

- talk about future, past, or present situations;

- compare things and phenomena, etc. (procedural knowledge) [4, p. 34-35].

Lexical awareness deals with selected, topically related, relevant vocabulary, that students should learn during the course study. Guided by the European lexical minimum, the vocabulary means "specific notions» selected by J. A. van Eck and J. L. M. Trim for B2 (Vantage) [8, p. 120-140]. We distinguish the following lexico-semantic groups:

1) personal information (name, address, telephone number, date and place of birth, age, gender, marital status, nationality, origin, occupation, family, religion, likes and dislikes, character / manner, appearance);2) house and dwelling; environment (types of housing, kinds of rooms, garden, furniture, bed linen, home decor, price, services, home-amenities, regional and geographical features, flora and fauna); 3) social life (at home, at work, incomes, education, career ladder); 4) time out, entertainment and leisure activities (leisure, hobbies / interests, radio / television, cinema / theater / concerts / etc, exhibitions / museums, photography, intellectual and artistic preferences, sport, press and media); 5) travelling (public transport, private transport, traffic, holidays / vacation, accommodation, luggage, going abroad, traveler's registration documents); 6) people relationships (relationship names, invitations, correspondence, club`s membership, government and politics, offenses and justice, war and peace, social relations); 7) health and medicine (parts of the body, stamina, hygiene, illness and accidents, medical services, insurance); 8 ) education (training, subjects, studying, qualifications and exams); 9) shopping (shops services, goods, clothes and fashion, smoking, household goods, cost and money); 10) food and drinks (types of food and drinks, eating habits, eating out); 11) services (post office, telephone, telegraph, bank, police, embassy services, hospital, service station); 12) places (address, city traffic, location, distance, direction); 13) language (language understanding, language ethics, language barrier); 14) climate and weather.

Background knowledge of predictions, as well as knowledge of a particular context, can greatly facilitate the process of perception, analyzing and understanding audio messages and help predict the whole message understanding. While listening to the native speakers, they perceive not only the verbal forms but also its meaning. Background knowledge includes geographical realities (non-equivalent lexical units (pub, Tower, City), abbreviations $(B B C)$, names of events in the public and cultural life of the country (Gunpowder Night, Poppy Day, names of outstanding people and celebrities) and predicts vocabulary that is distinguished from the first language by lexical units, though the lexical connotation doesn`t change (drug-store, letter-box, tea).

Knowledge of background vocabulary and geographical realities can provide understanding of both linguistic and cultural pieces of information, because the meaning of such vocabulary contains a complex of cross-cultural knowledge. The background vocabulary includes separate words, phrases and sentences. They contain phrasal verbs, proverbs and sayings, idioms, collocations and acting as background knowledge in general content [4, p. 37].

The next ELC component is receptive skills or listening speech skills. As a component, receptive skills are an independent action, brought to perfection (error-free execution), using phonetic, lexical and grammatical materials in the process of receptive speech activity. Receptive skills are the crucial factor to form and develop listening skills. Speech receptive skills (as well as reproductive skills) are formed on different stages and have such characteristics as fluency, flexibility and continuity. General language awareness is the consequence to master skills in learning a foreign language. Internal self-control is a component of speech skills and it is formed simultaneously and in a complex way with the component [4, p. 38-39]. 
Guided by the researched studies and methodological literature [1, p. 38-39] we draw the conclusion that students should possess such general receptive phonetic, lexical and grammatical skills at B2 level (Independent User).

- easily perceive and distinguish sounds, sound combinations; intones, pauses, important elements of accent in the sentence, different types of utterances based on intonation, etc. (on the segmental level);

- to recognize, distinguish and understand the learned lexical units in the fluent speech, to take it audibly and correlate them with internal self-control using a certain sample that kept in the long-term memory;

- to recognize, distinguish and understand grammatical forms of speech at the morphological and syntactic level, to perceive by hearing and correlate them with a certain meaning, taken from the long-term memory using internal self-control.

The next component of the ELC is auditory skills. Speech skills are the ability to control speech activity in making communicative tasks in new communicative situations. Ability is the synthesis of skills, knowledge and awareness [6, p. 350]. Auditory skills are presented in accordance with the levels of audio message understanding:

1) fragmentary (discriminative) listening: grasping the incomplete sentences, points or just words or phrases, merely different sounds that are produced;

2) global listening: grasping the main points or general information of the context;

3) listening for details (listening for gist): grasping specific information, details that are relevant, important or necessary;

4) critical listening: grasping deep, clear understanding, analyzing what the speaker is saying and determine his agenda.

According to the Manual Relating Language Examinations to the CEFR, the User B2.1 should understand the main idea of the comprehensive speech on specific and general topics; have to tune in to accents, adequacy, dialect variations, and discussions on the related topics. The User B2.1 should follow a natural language argumentation modeling, even though the topic is rather familiar and explicitly marked [7].

Drawing the conclusion, it is worth mentioning that at B2.1 level students should understand audio texts for comprehensive and detailed listening. The audio texts should be topically relevant within the modules topics defined by the curriculum and should sound naturally with clear pronunciation produced either by a native speaker or through audio and video [4, p. 42-43].

The User B2.2 should understand main ideas of the complex texts, standard spoken language, live or broadcast texts with broad reading vocabulary and large degree of autonomy. Only excess background noise, inadequate structure of discourse and using of idioms may affect the ability to understand speech messages [7]. Consequently, students B2.2 level should function independently in a variety of academic and professional environments in English, although with a limited range of nuance and precision. Listening includes hearing of interviews, short academic conversations, news, announcements, conversations, stories or descriptions, which have a longer lasting.

The difference between B2.1 and B2.2 levels is the following: students at B2.1 level should understand the speech presented within the framework of complex texts on both concrete and abstract topics defined by the curriculum of a particular institution of higher education using comprehensive, detailed and selective understanding at a normal pace without or with a minimum amount of background noise. Students at B2.2 level should fluently understand audio messages on familiar and unfamiliar topics that are commonly used in the personal, social, academic or professional spheres, at the same levels (comprehensive, detailed and selective), but slightly longer and more complicated in linguistic terms, with an average person speaking at a normal pace and with the common background noise [4, p. 42-43].

Consequently, in order to check the global listening, students should have the following skills:

- define the topic of audio message;

- understand the general information of an audio message;

- understand the main idea of an audio message;

- highlight a keyword / phrase / to understand the main idea.

In order to check the listening for gist, students should have the following skills:

- perceive information and focus on the main points and separate parts of information, keeping in mind the main idea;

- divide the text into logical-semantic parts, highlight the facts;

- mark keywords / semantic structures of each semantic part;

- correlate logical connections between text elements.

Under the selective understanding of audio text, we mean the understanding of only certain text facts, the main idea or the communicative intention of the text, which is expressed explicitly. In other words, when the purpose of the listening is to find out some pieces of information, students should have the following skills:

- understand separate parts of the text;

- determine the communicative intention of the text.

J. A. van Ek and J. L. M. Trim pointed out that, the ability to determine the communicative intention of the text is necessary for B2 level. As a result, a listener must be able to determine the intention of the text: 1) provide the listener with relevant information; 2) influence the recipient in order to form a certain attitude, ideas, thoughts, feelings; 3 ) perform as a means of entertainment for the listener [8, p. 89].

Speech perception is related to the internal self-control of the course of this process, which can act either deliberately or involuntarily through appropriate psychophysiological channels of feedback. It is believed that it is compulsory to train students with compensatory skills that will help to ensure an adequate rate of students' processing of the received information. They are integrated and checked in the context of the three above mentioned levels of grasping the audio text (comprehensive, detailed, and selective):

- ignore certain unfamiliar LU and grammatical structures;

- take audio text naturally without focusing on details;

- guess unfamiliar LU with the help of: context, internationalisms, similar words from the native language, etc.;

- hold in the memory a large segment of the speech stream [4, p. 44].

Taking into consideration psychophysiological hypothesis of perception and hearing understanding, one can not ignore biased view as a linguistic or semantic. Thus, students should develop: 
- abilities of linguistic biased view;

- abilities of semantic biased view [4, p. 45].

Drawing the conclusion, it is worth mentioning that ELC is a compulsory component of the educational process and students monitoring activity. It is implied in practice based on purposeful reflection of knowledge, skills, abilities and awareness to perceive and grasp audio messages. The research perspectives are comprehended in determining the components of speech competence in reading, writing and speaking at B2 level in the context of linguistic-pedagogical discourse.

\section{References:}

1. Golovach Y. V. Control of the level of formation of professional phonetic competence of students of the first year of the linguistic pedagogical university (on the material of the English language): Dis. ... Candidate ped. sciences: 13.00.02. K., 1997. 189 p.

2. Common European Framework of Reference for Languages: Learning, Teaching, Assessment. Language examining and test development (2002) [prepared under the direction of M. Milanovic (A.L.T.E.)]. Strasbourg: Language Policy Division, 55 (in English).

3. Kolosovskaya I. G. Teaching of students of general educational institutions for the perception and understanding of foreign language speech by ear (English as a second foreign language): dissertation to acquire a student degree Candidate ped Sciences on specialty. 13.00.02. Minsk, 2009. $24 \mathrm{p}$

4. Krapchatova Ya. A. (2014). Methodology of organizing of self- and peer assessment of English listening competence for future philologists. A candidate of sciences thesis in the specialty 13.00.02 Kyiv, Kyiv National Linguistic University, 22p. (in Ukrainian).

5. Nikolayeva S.Y. Goals of teaching foreign languages in the aspect of competence approach. Foreign languages. 2010. No. 2. P. 11-17.

6. Shchukin A. N. Lingvodidactic encyclopaedic dictionary: more than 2000 units. M.: Astrel: AST: The Guardian, 2007. 746 p.

7. Manual Relating Language Examinations to the CEFR Council of Europe. URL: http://relex.ecml.at/Resources/tabid/1231/language/ en-GB/Default.aspx

8. Van Ek J. A., Trimm L. M. Vantage. Cambridge : Council of Europe, 2001. 187 p. 